\title{
Spatial Competition and Marketing Strategy of Fast Food Chains in Tokyo
}

\author{
Kenji IshIZAKI* \\ Key words: spatial competition, marketing strategy, nearest-neighbor spatial association analysis, \\ fast food chain, Tokyo
}

\section{INTRODUCTION}

One of the important tasks of retail and restaurant chain expansion is the development of a suitable marketing strategy. In particular, a location strategy needs to be carefully determined for such chains, where store location is often the key to the successful corporate's growth (Ghosh and McLafferty, 1987; Jones and Simmons, 1990). A number of chain entries into the same market can cause strong spatial competition. As a result of this, retail and restaurant chains are anxious to develop more accessible and well-defined location strategies. In restaurant location, various patterns are respectively presented according to some types of restaurants (i.e. general full service, ethnic, fast food and so on) and stores of the same type are clustered along roads or in downtown areas (Pillsbury, 1987). It is inevitable that one chain store will compete with another chain store, both attempting to scramble for a "good location". However, it is also possible that the segregation of store distributions appear in consequence of spatial avoidance between chains.

The purpose of this paper is to analyze spatial competitions of the store distributions in fast food (hamburger) chains and to examine the relationships between spatial competition and location strategies.

\section{MEASURE OF SPATIAL COMPETITION}

The nearest-neighbor spatial association analysis described by Lee (1979) is capable of measuring the spatial competition between two distributions of points, while Clark and Evans (1954) describe a statistic utilizing only a single set of points. This measure is suitable for describing the store distribution of competing firms such as retail chains.

The nearest neighbor spatial association value, $R$, is obtained as follows:

$$
R=r_{0} / r_{E}
$$

The average nearest-neighbor distance, $r_{0}$, is given by

$$
r_{0}=\left(\sum_{i=1}^{N_{A}} d_{A_{i}}+\sum_{j=1}^{N_{B}} d_{B_{j}}\right) / N
$$

where $d_{A_{i}}$ is the distance between point $i$ in type A distribution and its nearest-neighbor point in type B distribution and $d_{B_{j}}$ is the distance from point $j$ of type $\mathrm{B}$ to its nearest neighbor point of type A. $N_{A}$ and $N_{B}$ are the numbers of points in each of the two types, and $N$ is the total number of points (hence $N=N_{A}+N_{B}$ ).

The expected mean distance is given by

$$
r_{E}=n_{A} / 2 \rho_{B}^{1 / 2}+n_{B} / 2 \rho_{A}^{1 / 2}
$$

where $n_{A}$ and $n_{B}$ are the proportions of the total points in type $\mathrm{A}$ and type $\mathrm{B}$, and $\rho_{A}$ and $\rho_{B}$ are the densities of points in each of the two types.

$R$-value less than unity indicates spatial clustering while a value greater than unity indicates spatial avoidance.

This method has been applied to the store distributions of retail chains (see Lee, 1979; Lee and Schmidt, 1980), and the spatial patterns of banking offices (Lord and Wright, 1981), who suggest that this measure provides some insights into the competitive location strategies of firms (Lord and Wright, 1981, p. 192).

\footnotetext{
* Graduate student, Tokyo Metropolitan University, Hachioji, Tokyo 192-03, Japan
} 


\section{SETTING}

The empirical setting is identical to that outlined in Ishizaki (1990), which examined the store distributions of four fast food chains for Tokyo in 1987, which consisted of 23 wards. This data is also updated by using additional information on chain store locations for 1994, obtained using a telephone directory (Yellow Page) as a source.

This study area has experienced a rapid growth of fast food stores since the appearance of McDonald's in 1971. McDonald's and Mos Burger have continuously developed to today, while the expansion of two other chains, Lotteria and Morinaga Love, have been stable (see Table 1). In particular, the growth of Mos Burger has outstripped that of McDonald's during seven years from 1987. One reason for this is that Mos Burger has mainly developed a franchising chain operation which can grow rapidly in a short time because less capital investment is required.

Figure 1 shows the distribution of fast food stores in 1987 and 1994. Fast food stores have mainly been located along railroads or subways, especially clustering at terminal stations or shopping cores such as Shibuya, Shinjuku and Ikebukuro. The concentration of stores on western Tokyo also implies that some chains have targeted younger customers because of the relatively high density of population aged from 15 to 34 in western Tokyo.

It is clearly indicated that all chains have expanded ubiquitously in the whole study area. Therefore the study area definition and the dispersion of selected fast food chain stores can be considered an ideal setting to apply nearest-

Table 1. Number of fast food stores in Tokyo

\begin{tabular}{lrrrr}
\hline \hline \multirow{2}{*}{ Fast food chain } & \multicolumn{3}{c}{ Number of stores } \\
\cline { 2 - 5 } & \multicolumn{2}{c}{1987} & \multicolumn{2}{c}{1994} \\
\hline McDonald's & 105 & $(40.4)$ & 132 & $(37.3)$ \\
Mos Burger & 76 & $(29.2)$ & 145 & $(41.0)$ \\
Lotteria & 53 & $(20.4)$ & 49 & $(13.8)$ \\
Morinaga Love & 26 & $(10.0)$ & 28 & $(7.9)$ \\
\hline Total & 260 & $(100.0)$ & 354 & $(100.0)$ \\
\hline
\end{tabular}

The figure in parenthesis is the percentage. neighbor analysis.

There is, however, a problem known as "edge effects" (Boots and Getis, 1988) in that the nearest-neighbor value depends on delimitation of the study area. Tokyo ( 23 wards) is bounded with physical barriers: the southeastern part of the edge is contiguous to Tokyo Bay and the southwestern and the northeastern parts are limited along large rivers. There is not any barriers in the northwestern part, but nearestneighbor distances for those points within the study area would exhibit little change even though stores outside of the study area are taken into account, due to a higher density store distribution in the northwestern part.

\section{ANALYSIS}

The results of applications of the nearestneighbor analysis (Clark and Evans, 1954) and the nearest-neighbor spatial association analysis are shown by Table $2^{1)}$ and Table 3.

Table 2 shows the clustered store distribution of McDonald's and Morinaga Love in 1987. Both of the nearest-neighbor statistics are significantly different from unity at the 0.05 level or the 0.01 level. Morinaga Love has a particularly clustering tendency because of a concentration to the south of the city center (see Fig.1). This is perhaps because the stores are agglomerated around the head office of Morinaga confectionery, the company which established Morinaga Love.

The nearest-neighbor spatial association values in Table 2 indicate that there is some variance in spatial competition among the different pairs of fast food chains. Since all nearest-neighbor spatial association values for McDonald's with other chains are significantly different from unity, these spatial associations are more clustered than random. This implies that McDonald's stores are actively competing with other chain stores, especially strongly competing with Lotteria. On the other hand, the store distribution of Mos Burger is relatively weakly competing with each of chains. These results suggest that the different location strategy of each chain results in a varied store distribution and also determines the degree of spatial competition. Ishizaki (1990) recognized the ex- 


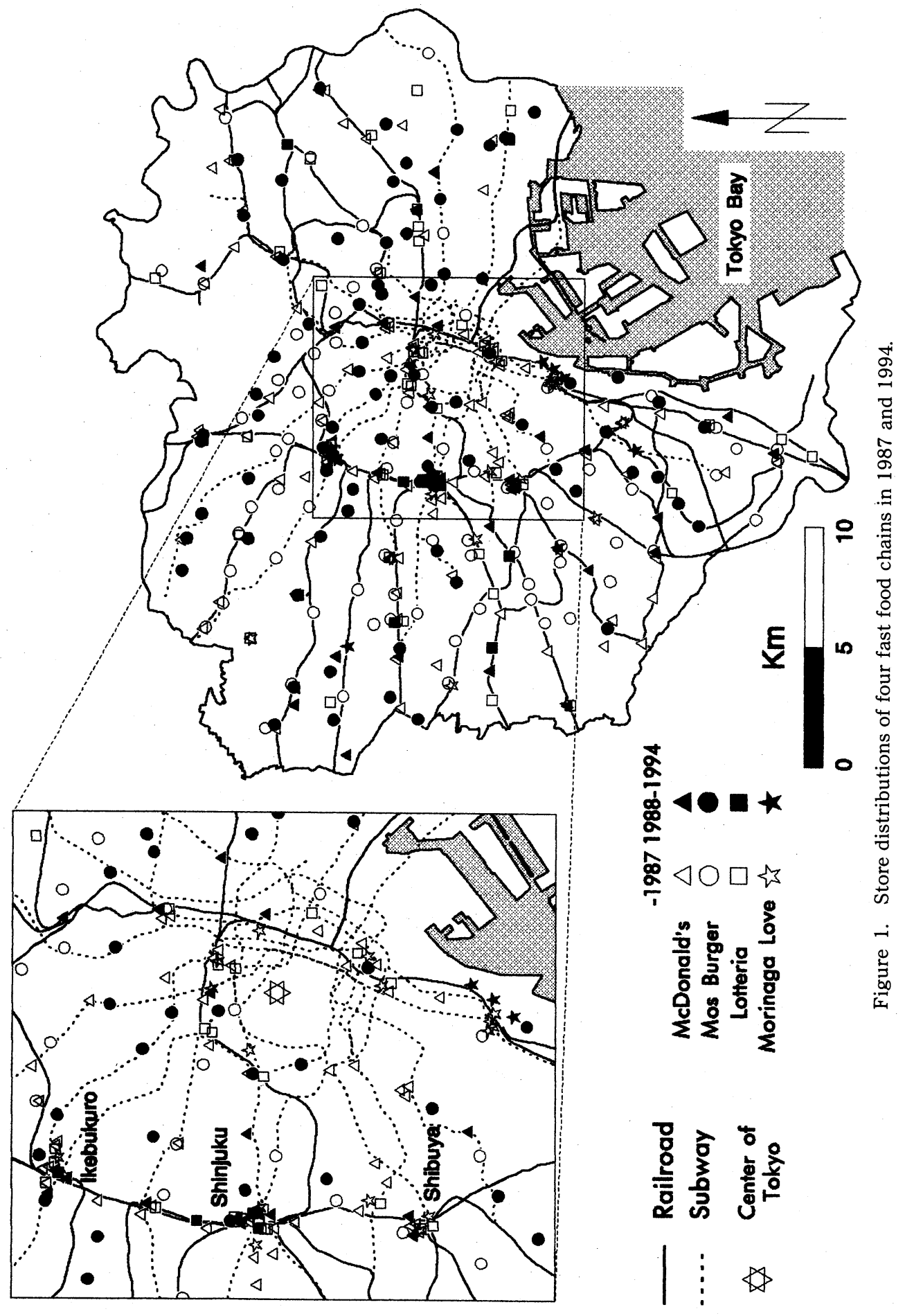


Table 2. Nearest-neighbor statistics and nearest-neighbor spatial association values for the fast food stores in 1987

\begin{tabular}{lcccc}
\hline \hline & McDonald's & Mos Burger & Lotteria & Morinaga Love \\
\hline McDonald's & $0.892^{* *}$ & & & \\
Mos Burger & $0.885^{*}$ & $1.109^{* *}$ & & \\
Lotteria & $0.677^{*}$ & 0.926 & 0.907 & \\
Morinaga Love & $0.841^{*}$ & $1.112^{* *}$ & 0.907 & $0.698^{*}$ \\
\hline
\end{tabular}

*. Significantly different from unity at the 0.01 level.

**: Significantly different from unity at the 0.05 level.

Nearest-neighbor statistics are on diagonal line.

Table 3. Nearest-neighbor statistics and nearest-neighbor spatial association values for the fast food stores in 1994

\begin{tabular}{lcccc}
\hline \hline & McDonald's & Mos Burger & Lotteria & Morinaga Love \\
\hline McDonald's & $0.902^{* *}$ & & & \\
Mos Burger & $0.734^{*}$ & $1.077^{* *}$ & & \\
Lotteria & $0.710^{*}$ & $0.863^{*}$ & 0.887 & \\
Morinaga Love & 0.943 & $1.251^{*}$ & 1.035 & $0.689^{*}$ \\
\hline
\end{tabular}

*. Significantly different from unity at the 0.01 level.

**: Significantly different from unity at the 0.05 level.

Nearest-neighbor statistics are on diagonal line.

istence of different location decisions in each of McDonald's and Mos Burger. McDonald's has clustered to large shopping cores as a result of seeking to capture customers shopping or at work. Thus the stores have competed severely with other chains which prefer a higher density of customers during the day. However, Mos Burger has favored the residential area with a higher density of night-time activity and also selected sites with low-priced land values. Therefore the pattern of Mos Burger stores exhibits characteristics of spatial avoidance compared to the patterns of other chain stores.

Table 3 shows that the spatial patterns of fast food stores in 1994 are different from those in 1987. The nearest-neighbor spatial association values represent different conditions of spatial competition, while the nearest-neighbor statistics slightly differ (see Table 2). The nearestneighbor spatial association values for McDonald's against Lotteria and McDonald's against Morinaga Love are somewhat greater than those in 1987. On the other hand, the values between Mos Burger and McDonald's or Lotteria indicate clustering tendencies. In fact, McDonald's has located stores dispersedly and Mos Burger has expanded into the shopping cores where other chain stores have also agglomerated during the seven years from 1987 (see Fig. 1). These results implicitly indicates that location strategy and site selection of each chain have changed since 1987.

\section{DISCUSSION}

It is often necessary for a retail chain to adopt a new strategy, when market conditions, competitors behavior and corporate environment are changed. The successful retail chain may explore a number of possible strategies (Jones and Simmons, 1990, p.388). Location strategy is the most important marketing strategy for retail chain, reflecting information from two areas: firstly, the internal environment such as corporate markets, objectives and capital resources and secondly, the external environment, including demographic characteristics, consumer expenditure, and competition (Mercurio, 1984). It seems that demographic characteristics and consumer expenditure in the external environment are similar for each of fast food chains because of similar characteristics such as taste and price. However, the distribution of population during the day or night differs in a large city area like Tokyo. Each fast food chain would have adopted a specific location strategy which reflects both the internal and external environments. 
In order to examine location strategies of fast food chain stores in the study area, concentration of the store distribution is reported in Table 4. The coefficients in Table $4 \mathrm{~b}$ are obtained in the following manner: firstly, the study area is segmented by the average of daytime and night-time population densities aged from 15 to 34, which are the demographic characteristics mainly targeted by almost all chains (Table 4a and Fig.2) ${ }^{2)}$ and secondly, the coefficient, $c_{i}$, is obtained by

$$
c_{i}=\frac{n_{i}}{N} / \frac{s_{i}}{S}
$$

Table 4. Relationship between market segmentation and store distribution

a. Segmentation of regions by day-time and night-time population densities aged from 15 to 34 Day-time

\begin{tabular}{|c|c|c|c|c|}
\hline \multirow[b]{2}{*}{ r } & & & & \multirow{4}{*}{ Number of wards } \\
\hline & & - & + & \\
\hline \multirow[t]{3}{*}{ Night-time } & - & $6(276.17)$ & $4(51.13)$ & \\
\hline & + & $9(221.31)$ & $4(57.58)$ & \\
\hline & so & $\begin{array}{l}\text { average } \\
\text { average } \\
\text { parethesis is } \\
\text { Population Cen }\end{array}$ & $\begin{array}{l}\text { a, sq. km. } \\
\text { s of Japan in }\end{array}$ & \\
\hline
\end{tabular}

b. Concentration of the store distribution of each fast food chain

\begin{tabular}{|c|c|c|c|c|c|c|c|c|c|}
\hline \multirow{2}{*}{\multicolumn{2}{|c|}{ Year }} & \multicolumn{2}{|c|}{ McDonald's } & \multicolumn{2}{|c|}{ Mos Burger } & \multicolumn{2}{|c|}{ Lotteria } & \multicolumn{2}{|c|}{ Morinaga Love } \\
\hline & & - & + & - & + & - & + & - & + \\
\hline \multirow{2}{*}{1987} & - & 0.481 & 2.258 & 0.491 & 1.092 & 0.663 & 2.237 & 0.169 & 4.560 \\
\hline & + & 0.835 & 3.008 & 1.406 & 1.801 & 0.568 & 3.178 & 0.632 & 3.239 \\
\hline \multirow{2}{*}{1994} & - & 0.549 & 1.886 & 0.606 & 1.063 & 0.672 & 1.452 & 0.078 & 5.081 \\
\hline & + & 0.789 & 3.190 & 1.209 & 2.033 & 0.671 & 3.437 & 0.880 & 2.256 \\
\hline
\end{tabular}

Each segment shown by the sign of " + " or " - " follows the above table.

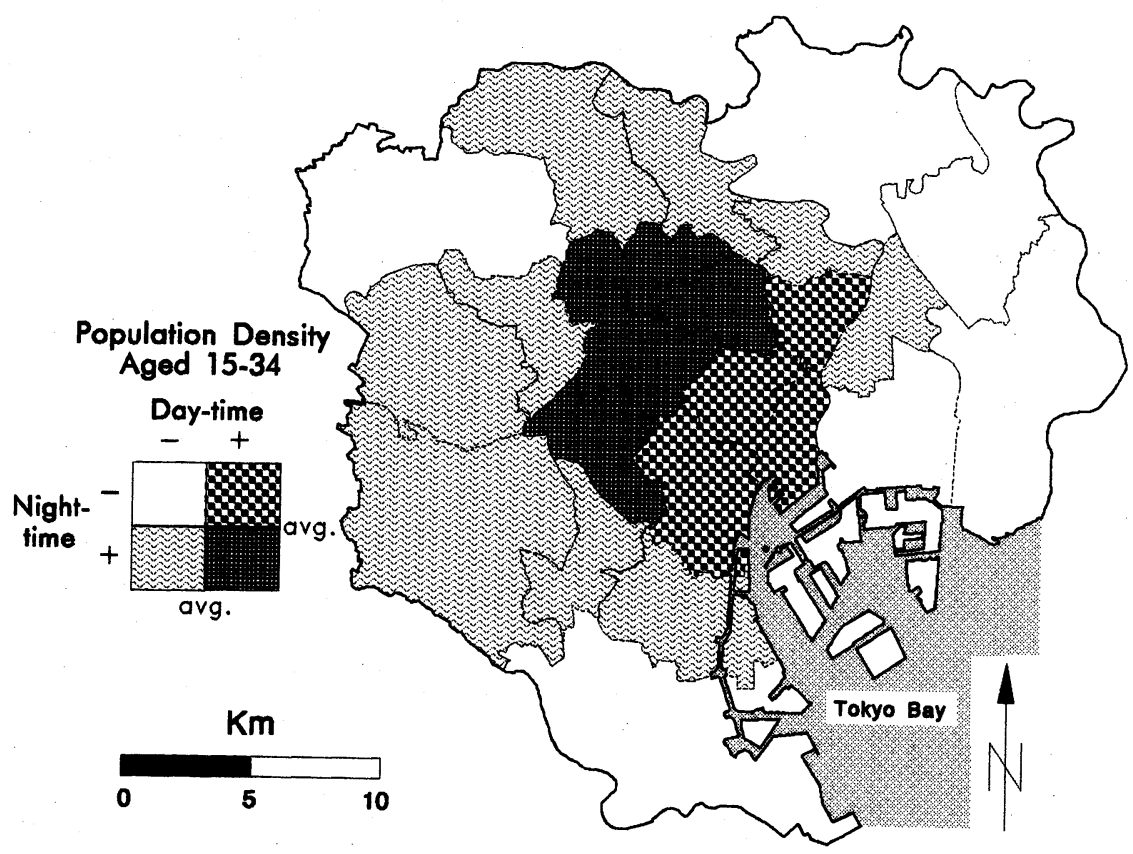

Figure 2. Market segmentation. 
where $n_{i}$ is the number of stores in the segmented regions $i, N$ is the total number of stores, $s_{i}$ is an area of the segmented regions $i$, and $S$ is a total area.

The results in Table 4 suggest the following points: (1) McDonald's and Lotteria have adopted location strategies which mainly targeted day-time population as the demand; (2) the location strategy of Mos Burger has changed from that mainly targeting night-time population to both night-time and day-time populations and (3) the target market of Mos Burger is apparently different from that of Morinaga Love. According to the classification of competitive status suggested by Kotler (1994), Lotteria as a "follower" has imitated the strategy of McDonald's as a "leader" and Mos Burger has targeted markets (regions) which have few stores of other chains present as a "nicher" until 1987, whilst adopting an offensive strategy as a "challenger" afterwards. This strategic change of Mos Burger was already confirmed in Ishizaki (1990) and the tendency would have been increasingly accelerated until 1994.

Thus the difference of target markets selected by each chain reflects distinct location strategies and leads to varied spatial competition. For example, the nearest-neighbor spatial association values for Mos Burger against Morinaga Love in Tables 2 and 3 indicate spatial avoidance or spatial segregation. In contrast, the spatial competition between chain stores targeting the similar markets tends to spatial clustering. Selecting target market may be determined by the condition of competition in the external environment and the corporate objectives within the internal environment for each chain.

Location strategy needs to be modified in response to changes in the internal and external environments. It is suggested that Mos Burger has altered location strategy markedly because of changes in the internal environment, such as modified target market (see Table 4) and increased capital resources from rapid growth. Competitive status shift can often result from capital accumulation (Shimaguchi, 1984, p. 248). The change of spatial competition for Mos Burger as described in the previous section may be due to the new location strategy undertaken, which tends to compete actively with other chain stores.

\section{CONCLUDING REMARKS}

The results of this paper suggest some variance and change in spatial competitions among fast food chains. Firstly, each of the nearestneighbor values for all chains shows little changes through 1987 to 1994 , whilst the patterns of McDonald's and Morinaga Love exhibit typical spatial clustering tendencies. Secondly, the nearest-neighbor spatial association values suggest spatial clustering for McDonald's against Lotteria and spatial avoidance for Mos Burger with other chains in 1987. Thirdly, Mos Burger tends to compete with other chains in 1994.

Various spatial competitions indicate different location strategies, such as selecting target markets and competitive status for each chain. When markets are segmented by day and night activity in the study area, McDonald's, Lotteria and Morinaga Love have targeted the markets with predominantly day-time activity, while Mos Burger has favored those with night-time activity in 1987. However, Mos Burger has also penetrated the markets with day-time activity with their modified location strategy in 1994.

Strategic change, as can be seen in Mos Burger's behavior, has given rise to the new condition of spatial competition. Fast food markets can change dramatically with interaction between spatial competition and marketing strategy.

\section{Acknowledgments}

The author wishes to thank Professor Yoshio Sugiura of the Department of Geography, Tokyo Metropolitan University, for his advice and encouragement.

(Received May 21, 1995)

(Accepted June 17, 1995)

\section{Notes}

1) Nearest-neighbor spatial association values in Table 2 are slightly different from those in previous paper (Ishizaki, 1990). This reason is that the distance between stores was calculated by mesh units (about $500 \mathrm{~m}$ square) in Ishizaki 
(1990) as opposed to store sites in this paper.

2) The data for day-time and night-time population densities are obtained from Population Census of Japan in 1990, the middle year between 1987 and 1994. Selecting an age group between 15 and 34 is based upon a hearing survey in Ishizaki (1990).

\section{References}

Boots, B. N. and Getis, A. (1988): Point pattern analysis. SAGE Publications, $93 \mathrm{p}$.

Clark, P. J. and Evans, F. C. (1954): Distance to nearest neighbor as a measure of spatial relationships in populations. Ecology, 35, 445-453.

Ghosh, A. and McLafferty, S. L. (1987): Location strategies for retail and service firms. Lexington Books, $212 \mathrm{p}$.

Ishizaki, K. (1990): The geographical development of fast food stores in Tokyo city area from viewpoint of locational policy. Annals of the Japan Association of Economic Geographers, 36, 129-140. (J)

Jones, K. and Simmons, J. (1990): The retail environ- ment. Routledge, $492 \mathrm{p}$.

Kotler, P. (1994): Marketing management: analysis, planning, implementation, and control. 8th ed., Prentice-Hall, $801 \mathrm{p}$.

Lee, Y. (1979): A nearest-neighbor spatial association measure for the analysis of firm interdependence. Environment and Planning A, 11, 169-176.

Lee, Y. and Schmidt, C. G. (1980): A comparative location analysis of a retail activity: the gasoline service station. The Annals of Regional Science, 14, 65-76.

Lord, J. D. and Wright, D. B. (1981): Competition and location strategy in branch banking: spatial avoidance or clustering. Urban Geography, 2, 189-200.

Mercurio, J. (1984): Store location strategies. Davies, R. L. and Rogers, D. S. eds.: Store location and store assessment research. John Wiley \& Sons, 237-262.

Pillsbury, R. (1987): From hamburger alley to hedgerose heights: toward a model of restaurant location dynamics. Professional Geographer, 39, 326-344.

Shimaguchi, M. (1984): Senryakuteki maketingu no ronri (Logic of strategic marketing). Seibundoshinkosha, Tokyo, $308 \mathrm{p}$. (J) 


\title{
ファーストフード・チェーンにおける空間的競合とマーケティング戦略
}

\author{
石 㠃 研 二*
}

本稿では, 東京都 23 区におけるファーストフード店 の空間的競合の分析を行ない, その立地戦略との関係に ついて考察した。最近隣尺度および最近隣随伴尺度を用 いて, 1987 年と 1994 年における店舗の分布を判定し た結果, 次のようなことがわかった。(1) 最近隣尺度は 1987 年と 1994 年でさほど変わりがなく, マクドナル ドと森永ラブには特徵的な集積パターンがみられる。(2) 最近隣随伴尺度によれば, 各チェーン間の組み合わせに よってばらつきがあり, 特にマクドナルドとロッテリア の空間的競合, モスバーガーと他のチェーンとの回避が 顕著である。(3) 特にモスバーガーは, 1994 年では, 他 のチェーンと集積する傾向にあり, 店舗の立地変化が確 認できる。次に, ファーストフードが対象とする, 年齢 15 34 歳の昼間人口密度と夜間人口密度で地域を分割
して, 各チェーンがいかなる市場をターゲットとしてい るかを検討した。その結果, 1987 年では, マクドナルド およびロッテリアは昼間人口を指向し, モスバーガーは 夜間人口を指向するが, 1994 年においては, モスバー ガーは他のチェーン店がターゲットとする昼間人口密度 が卓越した市場へあ進出を始めている。このような各 チェーンにおけるターゲット市場の相違は, 競争上の地 位や企業の目標などの違いに起因する立地戦略の差異を 反映している。また, モスバーガーにみられるように, ターゲット市場の変更や資金の増大に伴い, 立地戦略を 変更する企業むある。先に検証した様々な空間的競合 は, ターゲット市場の選定に代表される立地戦略の相違 を表わしているといえよう。 